\title{
An Example of the Application of the Cuex Methodology - the Calculated Exposure Resulting from Routine Stack Releases from the Haddam Neck Nuclear Power Plant
}

\author{
Fred H. Sweeton
}




\section{Printed in the United States of America. Available from National Technical Information Service \\ U.S. Department of Commerce \\ 5285 Port Royal Road, Springfield, Virginia 22161 \\ Price: Printed Copy $\$ 4.00$; Microfiche $\$ 2.25$}

This report was prepared as an account of work sponsored by the United States Government. Neither the United States nor the Energy Research and Development Administration, nor any of their employees, nor any of their contractors, subcontractors, or their employees, makes any warranty, express or implied, or assumes any legal liability or responsibility for the accuracy, completeness or usefulness of any information, apparatus, product or process disclosed, or represents that its use would not infringe privately owned rights. 


\section{DISCLAIMER}

This report was prepared as an account of work sponsored by an agency of the United States Government. Neither the United States Government nor any agency Thereof, nor any of their employees, makes any warranty, express or implied, or assumes any legal liability or responsibility for the accuracy, completeness, or usefulness of any information, apparatus, product, or process disclosed, or represents that its use would not infringe privately owned rights. Reference herein to any specific commercial product, process, or service by trade name, trademark, manufacturer, or otherwise does not necessarily constitute or imply its endorsement, recommendation, or favoring by the United States Government or any agency thereof. The views and opinions of authors expressed herein do not necessarily state or reflect those of the United States Government or any agency thereof. 


\section{DISCLAIMER}

Portions of this document may be illegible in electronic image products. Images are produced from the best available original document. 
Printed in the United States of America. Available from National Technical Information Service

U.S. Department of Commerce

5285 Port Royal Road, Springfield, Virginia 22161

Price: Printed Copy $\$ 4.00$; Microfiche $\$ 2.25$

This report was prepared as an account of work sponsored by the United States Government. Neither the United States nor the Energy Research and Development Administration, nor any of their employees, nor any of their contractors, subcontractors, or their employees, makes any warranty, express or implied, or assumes any legal liability or responsibility for the accuracy, completeness or usefulness of any information, apparatus, product or process disclosed, or represents that its use would not infringe privately owned rights. 
ORNL - TM-4781

UC-41 - Health and Safety

Contract No. W-7405-eng-26

ENVIRONMENTAL SCIENCES DIVISION

AN EXAMPLE OF THE APPLICATION OF THE CUEX METHODOLOGY--

THE CALCULATED EXPOSURE RESULTING FROM ROUTINE STACK

RELEASES FROM THE HADDAM NECK NUCLEAR POWER PLANT

Fred H. Sweeton

SEPTEMBER 1975

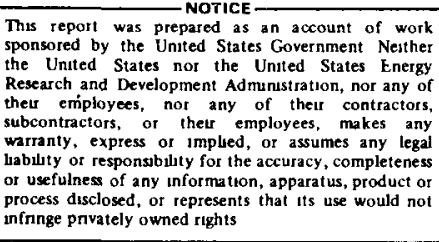

Environmental Sciences Division

Publication No. 672

NOTICE This document contains information of a preliminary nature and was prepared primarily for internal use at the Oak Ridge National Laboratory. It is subject to revision or correction and therefore does not represent a final report.

OAK RIDGE NATIONAL LABORATORY

Oak Ridge, Tennessee 37830

operated by

UNION CARBIDE CORPORATION

for the

U.S. ENERGY RESEARCH AND DEVELOPMENT ADMINISTRATION 
•

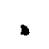


TABLE OF CONTENTS

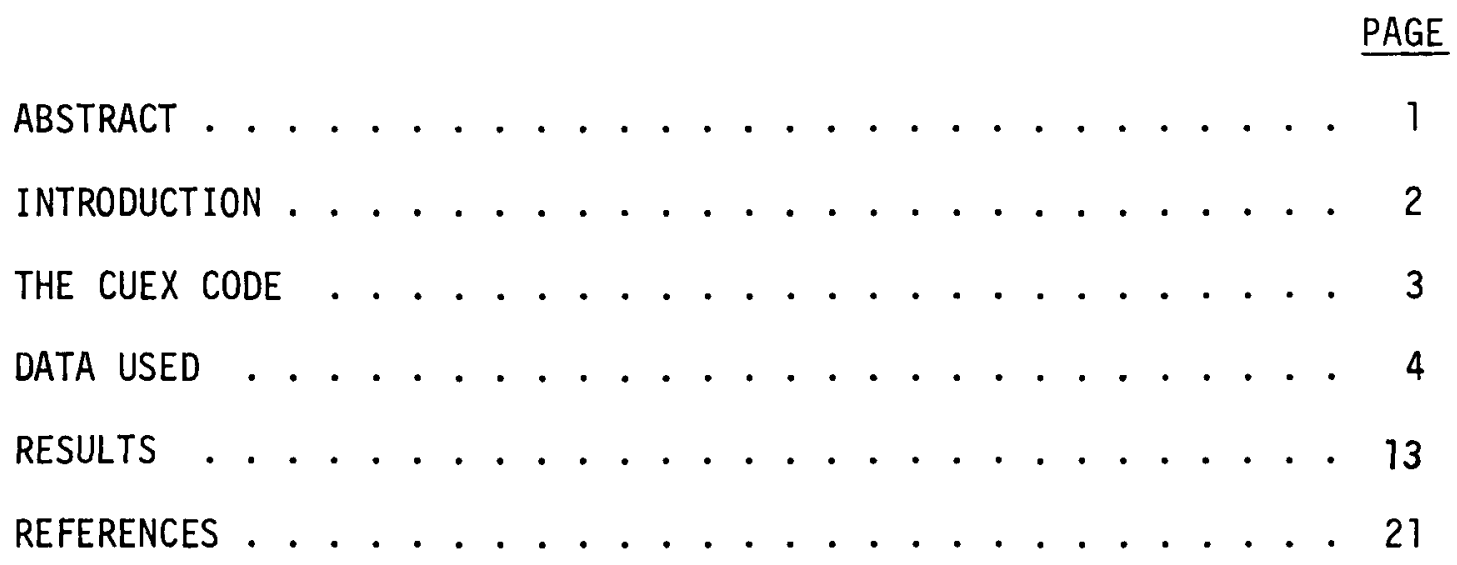




\section{LIST OF TABLES}

Number

Page

1 Input Values for Radionuclide-Independent Variables . . 7

2 Input Values for Radionuclide-Dependent Variables . . 8

3 Dose Conversion Factors Used in the Calculations . . 10

4 Average Figures per Square $\left(4 \mathrm{~km}^{2}\right)$. . . . . . . 12

5 Estimated Relative Air Concentration of ${ }^{85} \mathrm{Kr}$.... 14

6 Calculated Average Air Concentrations of Radio-

nuclides at Points Near the Haddam Neck Nuclear

Power Reactor .............. . 15

7 Estimated Relative Ground Deposition Rate of Iodine-131 . . . . . . . . . . . . . 16

8 Calculated Total Body Doses for the Different Nuclides ....................... 18

9 Calculated Results for Various Organs with Iodine-131 . 19 


\section{AN EXAMPLE OF THE APPLICATION OF THE CUEX METHODOLOGY-- THE CALCULATED EXPOSURE RESULTING FROM ROUTINE STACK RELEASES FROM THE HADDAM NECK NUCLEAR POWER PLANT}

Fred H. Sweeton

\section{ABSTRACT}

The CUEX (Cumulative Exposure Index) relates the concentrations of various nuclides in the environment to assigned annual dose limits. A computer code has been written to calculate this index for stack releases of radioactivity. This report is written to illustrate how the code in its present form can be applied to a particular reactor. The data used here are from the Haddam Neck (Connecticut Yankee) Nuclear Power Plant, a relatively large plant that has been in operation for 6 years. The results show that the highest exposure expected from the actual releases of gaseous ${ }^{85} \mathrm{Kr},{ }^{133} \mathrm{Xe},{ }^{131} \mathrm{I}$, and ${ }^{3} \mathrm{H}$ is about $0.2 \%$ of the "as low as practicable" 1 imits set by the Nuclear Regulatory Commission. Of the nuclides considered, ${ }^{133} \mathrm{Xe}$ is by far the most important; the chief mode of exposure to this nuclide is submersion in air. In the case of ${ }^{131} I$ the main exposure route is external irradiation from the activity on the ground except for the special case of the thyroid for which about $70 \%$ of the exposure arises from ingestion. 


\section{INTRODUCTION}

The CUEX concept has been described by Kaye et al. 'This index, which can be expressed in terms of the average air concentration of a particular radionuclide, is the time-integrated concentration that corresponds to a person's receiving an allowable annual dose from the nuclide via all modes of exposure. The modes involving inhalation and direct irradiation from air depend directly on the air concentration. The other modes are proportional for any particular case, but the actual ratios must be calculated for this case. The index can be related to particular organs of the body as well as to the whole body. In principle the CUEX concept could also be applied to liquid releases. A computer program utilizing the CUEX approach has been written for application to a plant releasing radionuclides to the atmosphere. In this program the CUEX is calculated for the hypothetical person in the vicinity of the plant who is expected to receive the greatest dose. In addition the calculation indicates the detailed mechanisms contributing to the dose.

This report is written to illustrate how this CUEX code can be applied to a real situation and to show the detailed results it gives. The Haddam Neck (Connecticut Yankee) Nuclear Power Reactor is used. This reactor is one of the pressurized-water type. It is relatively large and has been in operation a relatively long time. Its release of radioactive materials has been measured recently by the Environmental Protection Agency. ${ }^{2}$ 
THE CUEX CODE

The CUEX code in its present form has been written largely by R. E. Moore. Part of the detailed program is documented in the description of R. E. Moore's AIRDOS code, ${ }^{3}$ which calculates atmospheric dispersion and the resulting doses expected in squares of an assigned grid centered on the source.

The first part of the CUEX program calculates how radionuclides released from a point source become distributed over the surrounding countryside. For each radionuclide being considered, it is necessary to know the release rate and the mechanism of transport - whether as a gas, as an adsorbate on dust, or as a solute in rain drops. The meteorology of the area needs to be characterized in terms of the probabilities of various wind speeds and air stabilities in each of 16 directions. From this information the program estimates the average concentration of each radionuclide in the air at ground level at the center of each of 400 squares in a $20 \times 20$ grid. A similar calculation is made for the rate at which each radionuclide is being deposited on the ground in the same grid. The unit width of the squares can be set to any length of interest.

In the second part of the calculation, the square having the highest average air concentration of the first nuclide is determined. Then the calculated air concentration and ground deposition rates of this square are used to calculate the expected annual dose by all exposure modes for a person living in this square. These modes are intake from air to the lungs (inhalation); intake to the gastrointestinal tract (ingestion); and direct radiation from the nuclides in the air 
(immersion in air), in water (immersion in water), or on the ground (surface exposure). The calculation of exposure by the ingestion mode is based on the assumptions (1) that vegetables, beef, and milk produced in each square of the grid are contaminated according to the calculated air concentrations and ground deposition rates of that square; (2) that if enough of these foods are not produced within the grid, they are augmented by uncontaminated foods from outside; and (3) that the foods within the grid are comingled so that everyone in the grid ingests the same amount of radioactive material.* The program then calculates the expected dose, relates it to a given dose limit, and indicates the fraction of this exposure coming via each of the five exposure modes. This is done for several organs of the body when the appropriate dose conversion factors are available.

The program repeats this calculation for each of the radionuclides and then calculates the total dose for each organ from all the nuclides and shows the relative contribution of each.

\section{DATA USED}

The Haddam Neck (Connecticut Yankee) Nuclear Power Reactor is a pressurized-water plant located on the Connecticut River in an area having a relatively high population density. It started operation in

*Exposures for ${ }^{3} \mathrm{H}$ calculated by this code are likely to be high because $3 \mathrm{H}$, unlike the other nuclides, becomes directly tied to the water being cycled. Since the calculated ${ }^{3} H$ dose shown later is relatively small, the ${ }^{3} \mathrm{H}$ dose will not be recalculated by other methods, as it could be if needed. 
1968 and has a rating of 1825 megawatts thermal and 646 megawatts electrical.

The stack is 53 meters high, ${ }^{4} 7.8$ meters in diameter, and has a discharge rate of $1000 \mathrm{~m}^{3} / \mathrm{min}$.

Of the nearly 20 radionuclides whose release rates have been measured by the Environmental Protection Agency four were chosen for this calculation. They are listed below along with their measured release rates:

$$
\begin{aligned}
& \text { Krypton-85 }--0.539 \times 10^{7} \mathrm{pCi} / \mathrm{sec} \\
& \text { Xenon-133 }--0.634 \times 10^{8} \mathrm{pCi} / \mathrm{sec} \\
& \text { Iodine-131 -- } 0.444 \times 10^{3} \mathrm{pCi} / \mathrm{sec} \\
& \text { Hydrogen-3 -- } 0.507 \times 10^{7} \mathrm{pCi} / \mathrm{sec}
\end{aligned}
$$

The $\mathrm{Kr}$ and $\mathrm{Xe}$ nuclides were included because they contribute the greatest fraction of the total activity being released; ${ }^{131_{I}}$ and ${ }^{3} \mathrm{H}$ were chosen because of their special chemical and physical properties. The four nuclides are sufficient to illustrate how the CUEX program operates; additional nuclides could be included to give a complete picture.

The meteorological data were taken from the final environmental statement ${ }^{4}$ for this reactor, and are averages of readings taken at the plant site from a 100-foot tower over a period of a year. In processing these data for use in the program, the periods of "Unstable" conditions were divided equally between the Pasquil1 5 " $\mathrm{A}$, " "B," and "C" stability categories, and the periods of "Very Stable" conditions were divided equally between the "F" and "G" categories. In calculating the fractional 
time the wind blows at various directions and speeds, the times of calm were ignored and the other times were increased proportionally to total $100 \%$. This procedure has the effect of womewhat increasing the calculated radiation level at a distance from the stack at the expense of that near the stack. The hight of the lid was taken to be 600 meters, the average of winter and summer averages for this location. 6

The deposition parameters used for the radionuclides are shown below:

\begin{tabular}{|c|c|c|c|}
\hline Nuclide & $\begin{array}{l}\text { Gravitational } \\
\text { Fal1 Velocity } \\
\left(\mathrm{m}-\mathrm{sec}^{-1}\right) \\
\end{array}$ & $\begin{array}{l}\text { Deposition } \\
\text { Velocity } \\
\text { (m-sec-1) }\end{array}$ & $\begin{array}{l}\text { Scavenging } \\
\text { Coefficjent } \\
\left(\mathrm{sec}^{-1}\right) \\
\end{array}$ \\
\hline $85_{\mathrm{Kr}}$ & 0.0 & 0.00 & 0.0 \\
\hline${ }^{131} \mathrm{Xe}$ & 0.0 & 0.00 & 0.0 \\
\hline $131_{I}$ & 0.0 & 0.01 & $0.275 \times 10^{-5}$ \\
\hline $3_{H}$ & 0.0 & 0.00 & $0.275 \times 10^{-5}$ \\
\hline
\end{tabular}

The gravitational fall velocities were all set to zero, because none of the nuclides was expected to be associated with particles large enough to speed its descent to the ground. The deposition velocities of all nuclides except ${ }^{131}$ I were set to zero, since only the ${ }^{131}$ I was expected to be adsorbed by the ground. The scavenging coefficients for ${ }^{85} \mathrm{Kr}$ and ${ }^{133} \mathrm{Xe}$ were set to zero because these gases are relatively insoluble in rain.

Table 1 and Table 2 give the data needed to calculate the dose from the calculated concentrations of the radionuclides in the air and from their calculated ground deposition rates. Table 1 has those 


\section{Table 1. Input Values for Radionuclide-Independent Variables}

NUABER OF NUCLIDES CONSI DEREC

INHALATION RATE OF MAN I CUBIC CENTIMETERS/HRI

OILUTION FACTOR FOR WATER FOR SHIMMING (CM)

FRACTION OF TIME SPENT SHIMMING

SOIL SURFACE AREA REQUIRED IC FURNISH FCCO CROPS FUR ONE MAN (SQUARE METERSI

PASTURE AREA PER COW (SOUARE meters)

DRY WE IGHT AREAL DENSITY OF MANS abOVE-SURFACE fOOO (KGS PER SUUARE METERI

DRY-WEIJHT AREAL GRASS DENSI IY (KGS PER SOUARE METER)

OEPTH OF PLOW LAYER (CM)

OIETARY CORRECTION FACTOR FUR ABOVE-SURFACE FOOO

DIETARY CORRECTION FAC TOR FOR UPTAKE FRCM SOLL

DIETARY CORREC TION FACTOR FOR BEEF

DIETARY CORRECTION FACTOR FOR MILK

RATE OF INCREASE OF STEER MUSCLE MASS (KG PER DAY)

MUSClE MASS OF STEER AT SLAUGhter (KG)

SOIL DENSITY (GRAMS PER CUBIC CEATIMETER)

FALLOUT CORREC IION FACIOR FOR ABOVE-SURFACE FOOO

FalloUt CORREC IION FACTOR FOR SOLL SURFACE BELOW FOOD

FALLUUT CORREC IION FACTOR FOR PASTURE

FRACTION OF BEEF HERD SL AUGH IERED PER CAY

TRANSFER RATE OF MILK FROM UDOER (PER CAY)

BEEF CONSUMPTION DF MAN (KG/CAY)

MILK CONSUMPTION OF MAN ILITERS/OAYI

TRANSFER RATE--ABOVE-SURFACE FOOD TO SOIL SURFACE (PER DAY)

TRANSFER RATE--PASTURE GRASS TO PASTURE SOIL (PER DAY)

TRANSFER RATE--SOIL POOL TO SOIL SINK (PER DAY)

TRANSFER RATE--PASIURE SCIL TO SOIL SIAK (PER DAY)

TRANSFER RATE--PASTURE SOIL TO PASTURE GRASS (PER DAY)

TRANSFER RATE--SOIL SURFACE IO SOIL PCCL (PER DAY)

MILK CAPACITY OF THE UDDER (LITERS)

above-surface foOd CONSUMPTICN OF MAA (KG/DAY)

GRASS CONSUMPIION OF COM IKG IOAY)

MILK PROOUCTION OF COW (LITERS/DAY)

MAXIMUM TOTAL PERCENI CONTRI EUTEO TC BE LISTEO IN JRGAN TOTALS

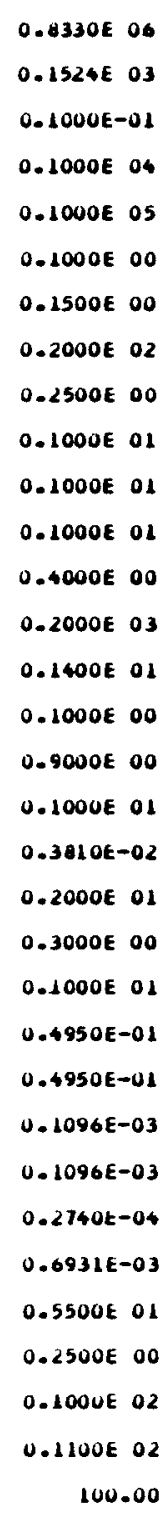

aNNUAL ORGAN DOSE LIMITS--

$\begin{array}{lr}\text { ORGAN } & \begin{array}{c}\text { OOSE LIMIT } \\ \text { (AEMSI }\end{array} \\ \text { TOT.BODY } & 0.005 \\ \text { GI TRACT } & 0.005 \\ \text { BONE } & 0.005 \\ \text { THYROID } & 0.015 \\ \text { LUNGS } & 0.005 \\ \text { MUSCLE } & 0.005 \\ \text { KIONEYS } & 0.005 \\ \text { LIVER } & 0.005 \\ \text { SPLEEN } & 0.005 \\ \text { TESTES } & 0.005 \\ \text { OVARIES } & 0.005\end{array}$


Table 2. Input Values for Radionuclide-Dependent Variables

CONCEVTRATION IN AIR CALCULATE) FOR REFERENCE SOUARE FROM SOURC TERM (MICROCURIE-HR/CUBIC CMI

$\mathbf{1 - 1 3 1}$

$0.1725 E-12$

0.0

$0.5200 E 00$

$0.1000 E$ DO

$0.5000 E$ OI

0. $8570 E-01$

$0.4950 E-01$

0.0

$0.1330 E-01 \quad 0.1330 E-01$

$0.7000 E-02$

$0.3000 E-01$

0.0

$0.9132 E-06$

$0.1348 E-11$

$0.9132 E-\infty$

$0.2904 E-08$

$0.5584 E-07$

$0.1725 E-12$
$1-3$

$0.2116 E-08$

0.0

$0.5200 E 00$

$0.1000 E 00$

0.5000E OI

0. 81 80E 00

$0.4950 E-01$

0.0

$0.1330 \mathrm{E}-\mathrm{O}$

$0.3000=-01$

0. 0

$0.9312 E-04$

$0.1558 E-07$

$0.9312 E-04$

$0.9527 E-06$

$0.7500 E-05$

$0.2116 E-08$ 
constants which do not change according to the radionuclide being considered. It includes the annual dose limits for the different organs. In general the limits used were the same as the "as low as practicable" 1 imits set by the Nuclear Regulatory Commission. ${ }^{7}$ The exceptions were the iodine dose limits for total body, G. I. tract, and lungs; for these, 5 mrem was used instead of 15. Al1 the limits used are much more stringent than those set by the International Commission on Radiological Protection. ${ }^{8}$ Table 2 gives the constants which depend on the radionuclide being considered.*

The dose conversion factors used in the calculation are shown in Table 3. These were obtained from the INREM and EXREM codes that have been described el sewhere. ${ }^{9,10}$

Figure 1 shows the grid overlaid on a map of Connecticut; its centerpoint is at the reactor on Haddam Neck. The $20 \times 20$ grid is made up of squares 2 kilometers on a side. For each of these squares the program requires the number of beef cattle, the number of milk cows, whether or not there is major production of vegetable crops, and the number of resident people. Data for these quantities were available ${ }^{11}$ on a county basis. Each square was assigned to a county, and the average county figures for $4 \mathrm{~km}^{2}$ were assigned. These numbers are shown in Table 4 . Since such a small part of the land in these counties is used for vegetable crops, only one square was designated as being devoted to these crops (since the code in its present state considers that either all or none of a square is used for food crops).

\footnotetext{
*These constants are not included for the two noble gases because the calculated dose is independent of these constants when all of the corresponding deposition parameters are set at zero.
} 
Table 3. Dose Conversion Factors Used in the Calculations

\begin{tabular}{|c|c|c|c|c|c|c|}
\hline \multirow[b]{2}{*}{ Nuclide } & \multirow[b]{2}{*}{ Organ } & \multicolumn{5}{|c|}{ Dose Conversion Factors } \\
\hline & & $\begin{array}{l}\text { Inhalation } \\
\qquad\left(\frac{\text { rem }}{\mu \mathrm{C} i}\right)\end{array}$ & $\begin{array}{l}\text { Ingestion } \\
\qquad\left(\frac{r e m}{\mu \mathrm{C} i}\right)\end{array}$ & $\begin{array}{c}\text { Submersion } \\
\text { in a ir } \\
\left(\frac{\mathrm{rem} \cdot \mathrm{cm}^{3}}{\mu \mathrm{C} \cdot \mathrm{hr}}\right)\end{array}$ & $\begin{array}{l}\text { Surface } \\
\text { Exposure } \\
\left(\frac{\mathrm{rem} \cdot \mathrm{cm}^{2}}{\mu \mathrm{C} j \cdot \mathrm{hr}}\right)\end{array}$ & $\begin{array}{l}\text { Submersion } \\
\text { in water } \\
\left(\frac{\mathrm{rem} \cdot \mathrm{cm}^{3}}{\mu \mathrm{Ci} \cdot \mathrm{hr}}\right)\end{array}$ \\
\hline${ }^{85} \mathrm{Kr}$ & Total body & 0 & a & 2.09 & a & a \\
\hline${ }^{133} \mathrm{xe}$ & Total body & 0 & a & $4.5 \times 10^{1}$ & $a$ & a \\
\hline \multirow[t]{4}{*}{${ }^{131} \mathrm{I}$} & Total body & $2.63 \times 10^{-3}$ & $3.50 \times 10^{-3}$ & $3.8 \times 10^{2}$ & $6.8 \times 10^{-2}$ & $8.1 \times 10^{-1}$ \\
\hline & Thyroid & 1.44 & 1.88 & $3.8 \times 10^{2}$ & $6.8 \times 10^{-2}$ & $8.1 \times 10^{-1}$ \\
\hline & G.I. tract & $1.07 \times 10^{-3}$ & $1.94 \times 10^{-3}$ & $3.8 \times 10^{2}$ & $6.8 \times 10^{-2}$ & $8.1 \times 10^{-1}$ \\
\hline & Lungs & $2.07 \times 10^{-2}$ & 0 & $3.8 \times 10^{2}$ & $6.8 \times 10^{-2}$ & $8.1 \times 10^{-1}$ \\
\hline \multirow[t]{2}{*}{${ }^{3} H$} & Total body & $1.08 \times 10^{-4}$ & $6.16 \times 10^{-5}$ & $0^{b}$ & 0 & $0^{b}$ \\
\hline & G.I. tract & $1.08 \times 10^{-4}$ & $6.16 \times 10^{-5}$ & 0 & 0 & 0 \\
\hline
\end{tabular}

${ }^{a_{N o t}}$ used when all the deposition constants are set at zero.

b These factors are for direct irradiation from outside the body. In the case of ${ }^{3} \mathrm{H}$ as $\mathrm{H}_{2} \mathrm{O}$, absorption through the skin can occur. That from the vapor has been taken into account by increasing the inhalation dose conversion factor by $75 \%$; that from absorbing liquid water when swimming, has been calculated to be negligible relative to that from inhalation. 


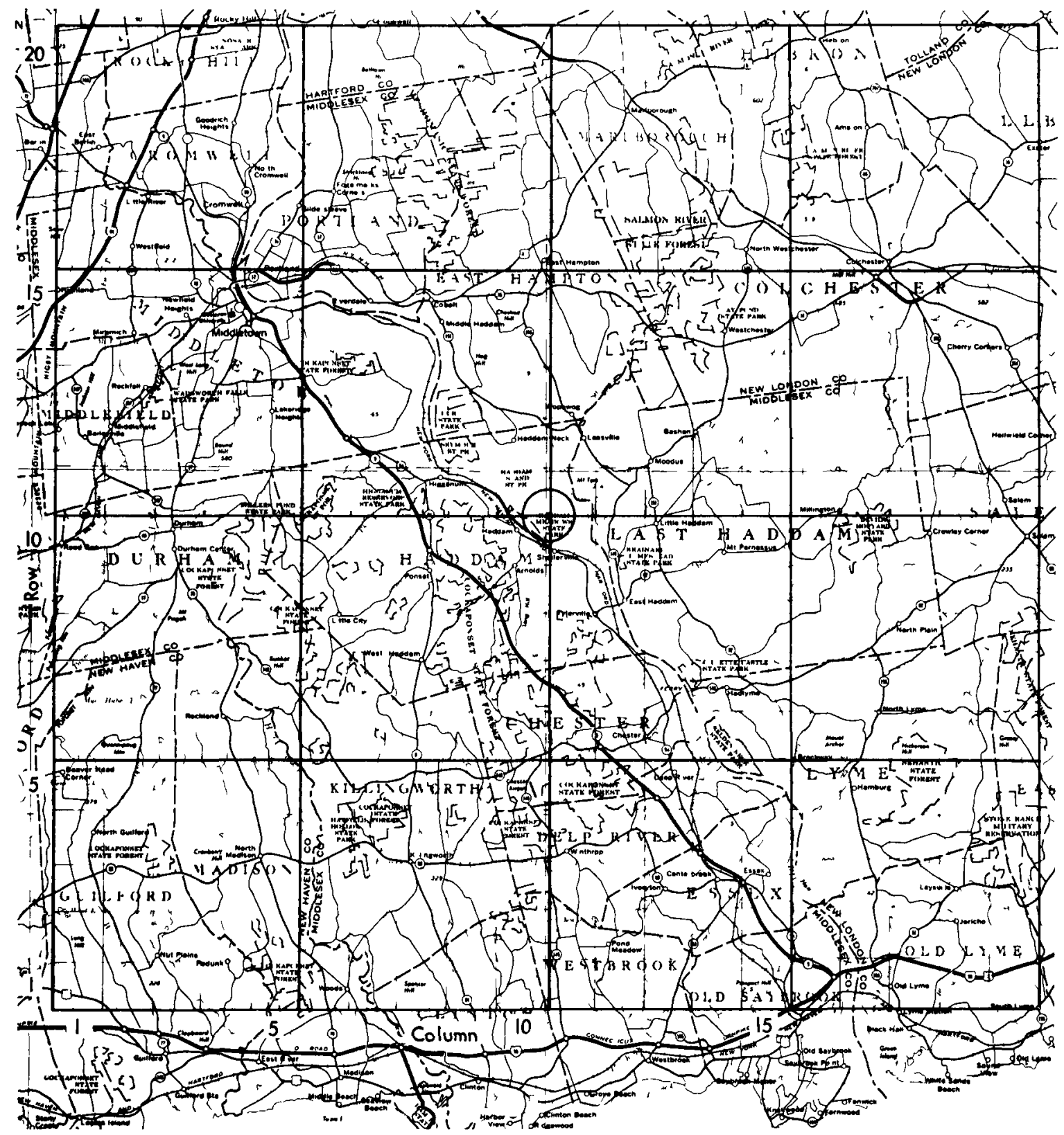

Fig. 1. Grid Used for Calculation 
Table 4. Average Figures per Square $\left(4 \mathrm{~km}^{2}\right)$

\begin{tabular}{lccccc}
\hline & \multicolumn{5}{c}{ County } \\
\cline { 2 - 6 } & Hartford & Middlesex & New Haven & New London & Tolland \\
\hline Number of beef cattle & 16 & 10 & 14 & 24 & 23 \\
Number of milk cows & 14 & 9 & 13 & 21 & 22 \\
Fraction area in food crops & 0.0016 & 0.00018 & 0.002 & 0.0002 & 0.0003 \\
Population & 1706 & 477 & 1904 & 534 & 384 \\
\hline
\end{tabular}




\section{RESULTS}

Table 5 indicates the average relative air concentration of ${ }^{85} \mathrm{Kr}$ calculated for the center of each square. Each square has been assigned to one of the 16 compass directions for which there is wind velocity data. The concentrations have been normalized to a reading of 100,000 for the maximum square. The actual reading for this maximum square $\left(\mathrm{pC} i / \mathrm{cm}^{3}\right)$ is shown in the heading at the top of the table. The readings in the table are presented in a geographical layout, the upper left figure applying to the northwest corner of the grid. The maximum calculated air concentration was in the square just to the southeast of the reactor. The square which represents Middletown, the largest city in this grid, is in the thirteenth row and the fourth column. The average ${ }^{85} \mathrm{Kr}$ concentration in air calculated for this square is $0.24 \mathrm{x}$ $10^{-6} \mathrm{pCi} / \mathrm{cm}^{3}$, which is approximately $15 \%$ of that in square with the maximum concentration. Table 6 lists the concentrations of the four radionuclides at Middletown and a few other clttes or towns in the grid. The calculated ground deposition rates for ${ }^{131} \mathrm{I}$ in the different squares of the grid are shown in Table 7 . These readings have been normalized to the maximum, just as was done with the air concentrations in Table 5 .

The method of calculating the atmospheric dispersion of radionuclides has been checked against field measurements made by the Environmental Protection Agency at the Haddam Neck reactor. Robert E. Moore, using this same atmospheric disperston code in his AIRDOS program, calculated $^{3}$ air concentrations at sampling points near the reactor and 
Table 5. Estimated Relative Air Concentration of ${ }^{85} \mathrm{Kr}$

$$
\text { Maximum }(100,000)=0.189 \times 10^{-5} \mathrm{pCi} / \mathrm{cm}^{3}
$$

RON

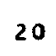

19

18

17

\begin{tabular}{|c|c|c|c|c|c|c|c|c|c|c|c|c|c|c|c|c|c|c|c|}
\hline & & & & & & & & & UMN & & & & & & & & & & \\
\hline 1 & 2 & 3 & 4 & 5 & 6 & 7 & 8 & 9 & 10 & 11 & 12 & 13 & 14 & 15 & 16 & 17 & 18 & 19 & 20 \\
\hline 4986 & 5228 & 5480 & 5735 & 2838 & 2954 & 3059 & 3146 & 2911 & 2942 & 2942 & 2911 & 2100 & $2 C_{4} 3$ & 1973 & 1896 & 2701 & 2584 & 2469 & 2358 \\
\hline 5228 & 5514 & 5816 & 6129 & 3059 & 3208 & 3346 & 3463 & 3230 & 3273 & 3273 & 3230 & 2311 & 2234 & 2142 & 2043 & 2881 & 2738 & 2600 & 2469 \\
\hline 5480 & 5816 & 6179 & 6565 & 6967 & 3505 & 3690 & 3852 & 3973 & 3690 & 3690 & 2650 & 2570 & 2462 & 2339 & $\$ 261$ & 3079 & 2903 & 2738 & 2584 \\
\hline 5735 & 6129 & 6565 & 7042 & 7555 & 8088 & 4100 & 4337 & 4516 & 4236 & 4236 & 3012 & 2893 & 2739 & 3761 & $35<1$ & $\$ 245$ & 3079 & 2881 & 2701 \\
\hline 0230 & 10975 & 6967 & 7555 & 8210 & 8924 & 4615 & 4957 & 5236 & 4976 & 4976 & 3490 & 3305 & 307 & 4141 & $38<2$ & 3527 & 3261 & 2379 & 2214 \\
\hline 10622 & 11476 & 12466 & 8088 & 8924 & 9883 & 10945 & 3765 & 6213 & 6050 & 6050 & 4135 & 3843 & $3 C 41$ & 4509 & 4141 & 3767 & 2711 & 2491 & 2301 \\
\hline 10975 & 11937 & 13081 & 14455 & 16117 & 10945 & 12456 & 14078 & 7597 & 7743 & 7763 & 5036 & 6432 & 5705 & 5041 & $\$ 528$ & 1155 & 2848 & 2593 & 2379 \\
\hline 1267 & 12326 & 13615 & 15211 & 17229 & 19830 & 14018 & 16622 & 9631 & 10633 & 10633 & 6365 & 7560 & 6432 & 4300 & 3714 & $\$ 325$ & 2967 & 2680 & 2446 \\
\hline 6830 & 7509 & 14014 & 15796 & 18130 & 21178 & 25008 & 30137 & 25020 & 16348 & 10918 & 11164 & 6887 & 5603 & 4679 & 3982 & 3450 & 3057 & $600<$ & 5513 \\
\hline 6896 & 7599 & 8478 & 9609 & 11124 & 13125 & 15843 & 19951 & 43609 & 45098 & 22346 & 10663 & 16590 & 12575 & 10644 & $89 \times 3$ & 1765 & 6848 & 0135 & 5566 \\
\hline 6896 & 7599 & 8478 & 9609 & 11124 & 13125 & $1584 b$ & 19951 & 13675 & $\forall 529$ & 99999 & 75454 & 16590 & 12975 & 10644 & 8993 & 7765 & 6848 & 6135 & 5566 \\
\hline 6030 & 7509 & 3712 & 4205 & 4853 & 5726 & 6938 & 3 & 5 & 4004 & 1 & 12 & 18 & 93 & 3 & & 07 & 20232 & 6062 & 5513 \\
\hline 2959 & 3249 & 3603 & 4043 & 4603 & 5328 & 2859 & 3404 & 2750 & 1237 & 7231 & 13181 & 51382 & 44184 & 29011 & $2500 y$ & 22020 & 19035 & 17712 & 16138 \\
\hline 2879 & 3142 & 6 & 4 & 42 & 2 & 2513 & 2859 & 2279 & 355 & 5356 & 10053 & 14 & 04 & 17 & 91 & 20892 & 18837 & 17133 & 15205 \\
\hline 2783 & 3016 & 3287 & 1610 & 1782 & 1980 & 2199 & 1803 & 1927 & 4488 & 4488 & 9136 & 4335 & 34847 & 31657 & 20722 & 26150 & 11920 & 16448 & 15183 \\
\hline 2676 & 2819 & 1380 & 1500 & 1035 & 1782 & 1403 & 1565 & 1640 & 3748 & 8 & 94 & 10 & os 14 & 22 & 20521 & $24+99$ & 22673 & 15705 & 24604 \\
\hline 1129 & 1209 & 1298 & 1395 & 1500 & 1610 & $1 s 11$ & 1481 & 1434 & $\$ 211$ & $\$ 211$ & 4 & osty & 6189 & 20150 & 24448 & $2\langle 407$ & 21419 & OSt & 14 \\
\hline 1077 & 1145 & 1219 & 1298 & 1380 & 1130 & 1186 & 12 & 1271 & 2813 & 2813 & 5997 & & 91 & & 22013 & 21419 & 20204 & 19009 & 16009 \\
\hline 1026 & 1084 & 1145 & 1209 & 99 & $103 y$ & 1 & 1117 & 2473 & 23 & $\angle>0$ & $24 / 5$ & so. & 4 & 14 & 4671 & 4 & 169 & 117 & 17214 \\
\hline 977 & 1026 & 1077 & 1128 & 920 & 962 & 94 & $10<0$ & $23 y$ & 2202 & 2262 & 234 & 4803 & 4611 & 224 & 4354 & 1 & 009 & 17214 & 16445 \\
\hline
\end{tabular}


Table 6. Calculated Average Air Concentrations of Radionuclides at Points Near the Haddam Neck Nuclear Power Reactor

\begin{tabular}{|c|c|c|c|c|c|c|}
\hline & \multicolumn{6}{|c|}{ Square } \\
\hline & Maximum & Middletown & Rocky Hill & Deep & River & Colchester \\
\hline Row & 10 & 14 & 20 & & 5 & 15 \\
\hline Column & 11 & 4 & 4 & & 13 & 17 \\
\hline${ }^{85} \mathrm{Kr}\left(\mathrm{pCi} / \mathrm{cm}^{3}\right)$ & $1.9 \times 10^{-6}$ & $0.27 \times 10^{-6}$ & $\times 10^{-6}$ & 0.74 & $\times 10^{-6}$ & $\times 10^{-6}$ \\
\hline${ }^{133} \mathrm{Xe}\left(\mathrm{pCi} / \mathrm{cm}^{3}\right)$ & $22.3 \times 10^{-6}$ & $3.2 \times 10^{-6}$ & $\times 10^{-6}$ & 1.6 & $\times 10^{-6}$ & $\times 10^{-6}$ \\
\hline${ }^{131} \mathrm{I}\left(\mathrm{pCi} / \mathrm{cm}^{3}\right)$ & $0.15 \times 10^{-9}$ & $0.014 \times 10^{-9}$ & $0.0042 \times 10^{-9}$ & 0.008 & $\times 10^{-9}$ & $0.0040 \times 10^{-9}$ \\
\hline${ }^{3} \mathrm{H}\left(\mathrm{pCi} / \mathrm{cm}^{3}\right)$ & $1.78 \times 10^{-6}$ & $0.25 \times 10^{-6}$ & $0.10 \times 10^{-6}$ & 0.13 & $\times 10^{-6}$ & $0.067 \times 10^{-6}$ \\
\hline
\end{tabular}


Table 7. Estimated Relative Ground Deposition Rate of ${ }^{131_{I}}$

$$
\text { Maximum }(100,000)=0.163 \times 10^{-9} \mathrm{pCi} \mathrm{cm} \mathrm{cm}^{-2} \mathrm{sec}^{-1}
$$

2ow

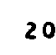

\begin{tabular}{|c|c|c|c|c|c|c|c|c|c|c|c|c|c|c|c|c|c|c|c|}
\hline \multirow[b]{2}{*}{ I } & \multirow[b]{2}{*}{2} & \multirow[b]{2}{*}{3} & \multirow[b]{2}{*}{4} & \multirow[b]{2}{*}{5} & \multirow[b]{2}{*}{$\circ$} & \multirow[b]{2}{*}{7} & \multirow[b]{2}{*}{8} & \multicolumn{2}{|c|}{ GOL UAN } & \multirow[b]{2}{*}{11} & \multirow[b]{2}{*}{12} & \multirow[b]{2}{*}{13} & \multirow[b]{2}{*}{14} & \multirow[b]{2}{*}{15} & \multirow[b]{2}{*}{10} & \multirow[b]{2}{*}{11} & \multirow[b]{2}{*}{16} & \multirow[b]{2}{*}{19} & \multirow[b]{2}{*}{20} \\
\hline & & & & & & & & 9 & 10 & & & & & & & & & & \\
\hline 102 & 2315 & 2541 & 2776 & 1653 & 1766 & 1809 & 1955 & 1910 & 1940 & 1940 & 1910 & 1310 & $1<5<$ & 1103 & $|10\rangle$ & 1542 & 1427 & 1316 & 1210 \\
\hline 2315 & 2572 & 2851 & 3145 & 1869 & 2017 & 2135 & $227<$ & 2224 & 2267 & 2267 & 2224 & 1524 & 1445 & 1352 & 1232 & 1721 & 1579 & 1443 & .1316 \\
\hline 2541 & 2851 & 3193 & 3563 & 3955 & 2314 & 2502 & 2607 & 2790 & 2686 & 2686 & 1860 & 1790 & 1619 & 1552 & 2107 & 1921 & 1744 & 1579 & 1427 \\
\hline 2776 & 3145 & 3563 & 4029 & 4539 & 5032 & 2428 & 3166 & 3336 & 3229 & 3229 & 2236 & $\angle 112$ & 1952 & 2635 & $23 * 2$ & $<142$ & 1921 & 1721 & 1542 \\
\hline 904 & 5625 & 3955 & 4539 & 5156 & 5885 & 3439 & 3795 & 4085 & 3987 & 3981 & 2740 & 2545 & $<300$ & 1029 & 2691 & $\alpha 3 \alpha$ & 2107 & 1570 & 1403 \\
\hline 5281 & 6123 & 7121 & 5032 & 5885 & 6877 & 1948 & 4640 & 5103 & 5019 & 5079 & 3420 & 3113 & 3975 & 3484 & 3029 & 2635 & $19 K$ & 1685 & 1694 \\
\hline 5625 & 6584 & 1754 & 91881 & 10877 & 7988 & 95851 & 11298 & 6540 & 6800 & 0806 & 4373 & 5404 & 607 & 3975 & 2769 & $23 \pi$ & 2055 & 1790 & 1570 \\
\hline 5913 & 6978 & 8307 & 99111 & 12069 & 148911 & 112981 & 13998 & 8668 & 9766 & 9766 & 5772 & 6676 & 5464 & 3648 & 5053 & 2554 & 2179 & 1679 & 1636 \\
\hline 3461 & 4079 & 87251 & 205311 & 13042 & 163802 & 200212 & 203512 & 229531 & 15650 & 10314 & 10524 & 6325 & 4961 & $\$ 979$ & 3249 & 2692 & 2272 & 4535 & 3956 \\
\hline 3525 & 4171 & 5074 & 6266 & 1896 & 100901 & 130971 & 17702 & 416164 & 45231 & 22143 & 10295 & 15720 & 11895 & 9404 & 7662 & 0348 & 5369 & 4612 & 4011 \\
\hline 3525 & 4171 & 5074 & 6266 & 7896 & 10040 & 130971 & 17102 & 12853 & 8506 & 99999 & 72944 & 15720 & 11895 & 9404 & 1002 & 6348 & 5369 & 412 & 011 \\
\hline 3461 & 4079 & 2028 & 2519 & M & 4101 & 5377 & 1240 & 4583 & 3745 & 18436 & 07901 & 42922 & 33065 & 26132 & 11091 & 17437 & 14023 & 4535 & 3950 \\
\hline 1315 & 1582 & 1921 & 2357 & 2926 & 3684 & 2033 & 2645 & 2294 & 6157 & 0157 & 11257 & 44150 & 36299 & 23855 & 14665 & 16511 & 13998 & 12000 & 20305 \\
\hline 1244 & 1483 & 1779 & 2148 & 2610 & 1418 & 1734 & 2083 & 1751 & 4315 & 4315 & 8668 & 36299 & 31168 & 26234 & 17952 & 15314 & 13168 & 11405 & 947 \\
\hline 1180 & 1368 & 1619 & 850 & 1011 & 1232 & 1416 & 1226 & 1362 & 3187 & 3187 & 6794 & 6150 & 26254 & 22001 & 19760 & 17054 & 12216 & 10705 & 9420 \\
\hline 1087 & 1244 & 651 & 750 & 87 & 1011 & 003 & 971 & 1058 & 2424 & 2424 & 5 & 4939 & 4430 & 19760 & 17449 & 15340 & 13467 & 9967 & 40 \\
\hline 439 & 505 & 580 & 6 & 75 & a & 709 & 7 & 6 & 4 & I & 3 & 1 & 3 & 4 & 01 & 17 & 04 & 46 & 40 \\
\hline 398 & 452 & 513 & 580 & 65 & 531 & 385 & 632 & 668 & 1494 & 1494 & 3518 & 3343 & 3112 & 2048 & 13407 & 12204 & 11002 & 9807 & 5070 \\
\hline 359 & 403 & 452 & 505 & 414 & 746 & 485 & 18 & 178 & 1201 & 1201 & 1178 & 2780 & 2625 & 24 & $\angle 2 \angle 9$ & 10866 & 5887 & 971 & 1223 \\
\hline & & & & & & & & & & & & & & & & & & & \\
\hline
\end{tabular}


found his values ranged from 56 to $156 \%$ of the values for ${ }^{85} \mathrm{Kr}$ and ${ }^{133} \mathrm{Xe}$ measured by the EPA.

For each nuclide being considered, the code then calculates the CUEX for each organ. If the appropriate dose conversion factor is not available, the code substitutes the total body value, and indicates this substitution on the printout. In addition, the code will calculate the CUEX in terms of the air concentration in any square when the corresponding concentration in the maximum square gives the allowable dose. In Table 8, which is for total body dose, the CUEX's listed are the ones appropriate for the maximum square. They show that, of these four nuclides, ${ }^{131}$ I can be least tolerated. However, when these CUEX's are compared to the actual average air concentrations calculated for this reactor, ${ }^{133} \mathrm{Xe}$ proves to give the most dosage (see fourth column) although still much less than the chosen dose limit. The last five columns show the relative contributions of each mode of exposure to the dose from each nuclide.

Table 9 shows how the CUEX program can differentiate the doses received by the various organs. The fourth column shows that the thyroid is the organ receiving the greatest ${ }^{131}$ I dose relative to the dose 7 imit, even though the dose limit for the thyroid has been set higher than for the other organs. The table shows that for total body, G. I. tract, and lungs, the greatest dose comes from surface exposure; but for the thyroid, the major mode is ingestion.

The calculation also shows the relative contribution of each nuclide to the dose received by each organ. Given below are such results for total body (which is treated in parallel with the individual organs): 
Table 8. Calculated Total Body Doses for the Different Nuclides

\begin{tabular}{|c|c|c|c|c|c|c|c|c|}
\hline \multirow[b]{2}{*}{ Nuclide } & \multirow[b]{2}{*}{$\begin{array}{l}\text { Dose limit } \\
\text { (rems/year) }\end{array}$} & \multirow{2}{*}{$\begin{array}{l}\text { CUEX at } \\
\text { max. square } \\
\left(\frac{p C i h r}{\mathrm{~cm}^{3} \mathrm{yr}}\right)\end{array}$} & \multirow[b]{2}{*}{$\begin{array}{l}\text { Fraction of } \\
\text { dose limit }\end{array}$} & \multicolumn{5}{|c|}{ Percent of dose according to mode } \\
\hline & & & & Inhalation & Ingestion & $\begin{array}{c}\text { Submersion } \\
\text { in air }\end{array}$ & $\begin{array}{l}\text { Surface } \\
\text { exposure }\end{array}$ & $\begin{array}{l}\text { Submersion } \\
\text { in water }\end{array}$ \\
\hline${ }^{85} \mathrm{Kr}$ & 0.005 & 2400 & 0.000007 & 0 & 0 & 100 & 0 & 0 \\
\hline${ }^{133} \mathrm{Xe}$ & 0.005 & 110 & 0.0018 & 0 & 0 & 100 & 0 & 0 \\
\hline $131 \mathrm{I}$ & 0.005 & 0.062 & 0.000022 & 2.7 & 6.6 & 0.5 & 90.2 & 0.1 \\
\hline $3_{H}$ & 0.005 & 47 & 0.00033 & 84.0 & 16.0 & 0 & 0 & 0 \\
\hline
\end{tabular}


Table 9. Calculated Results for Various Organs with Iodine-131

\begin{tabular}{|c|c|c|c|c|c|c|c|c|}
\hline \multirow[b]{2}{*}{ Organ } & \multirow{2}{*}{$\begin{array}{l}\text { Dose limit } \\
\text { (rem/year) }\end{array}$} & \multirow{2}{*}{$\begin{array}{l}\text { CUEX at } \\
\text { max. square } \\
\left(\begin{array}{ll}\mathrm{pC} i \mathrm{hr} \\
\mathrm{cm}\end{array}\right)\end{array}$} & \multirow{2}{*}{$\begin{array}{l}\text { Fraction of } \\
\text { dose limit }\end{array}$} & \multicolumn{5}{|c|}{ Percent of exposure by mode } \\
\hline & & & & Inhalation & Ingestion & $\begin{array}{l}\text { Submersion } \\
\text { in air }\end{array}$ & $\begin{array}{l}\text { Surface } \\
\text { exposure }\end{array}$ & $\begin{array}{c}\text { Submersion } \\
\text { in water }\end{array}$ \\
\hline Total body & 0.005 & 0.062 & 0.000022 & 2.7 & 6.6 & 0.5 & 90.2 & 0.1 \\
\hline G.I. tract & 0.005 & 0.065 & 0.000021 & 1.1 & 3.8 & 0.5 & 94.5 & 0.1 \\
\hline Thyroid & 0.015 & 0.0036 & 0.00037 & 29.1 & 69.2 & 0.0 & 1.8 & 0.0 \\
\hline Lungs & 0.005 & 0.055 & 0.000024 & 19.0 & 0.0 & 0.4 & 80.5 & 0.1 \\
\hline
\end{tabular}




\begin{tabular}{|c|c|}
\hline Nuclide & $\begin{array}{c}\text { Percent of } \\
\text { dose }\end{array}$ \\
\hline${ }^{133} \mathrm{Xe}$ & 83.0 \\
\hline $3_{H}$ & 15.6 \\
\hline${ }^{131_{I}}$ & 1.0 \\
\hline${ }^{85} \mathrm{Kr}$ & 0.3 \\
\hline
\end{tabular}

The program calculates the total dose of each organ from all the nuclides and then compares this to the dose limit. The highest ratio found was $0.2 \%$. This indicates that the release of these four radionuclides from the Haddam Neck reactor would result in overall dose rates that are only a small fraction of the dose limits which have been used.

In summary, the CUEX code has been applied to the routine stack releases from an operating nuclear power reactor. The amount of data required to define the system is large, but once these data are assembled the code easily calculates the maximum annual dose to be expected, and, in addition, breaks down the various contributions to the total dose in a manner to show what steps would be most productive in reducing the dose. The format of the code is such that it can be applied just as easily to radioactivity releases from mining and milling operations, fuel fabrication, and fuel reprocessing. 


\section{REFERENCES}

T. Stephen V. Kaye, R. S. Booth, P. S. Rohwer, and E. G. Struxness, "A Cumulative Exposure Index for Assessing Environmental Releases of Radioactivity," Proceedings International Symposium on Radioecology Applied to the Protection of Man and His Environment, EUR $4800 d-f-i-e$, Rome, September 7-19, 1971, p. 909.

2. Bernd Kahn et al., "Radiological Surveillance Study of the Haddam Neck PWR Nuclear Power Station," EPA-520/3-74-007 (1975).

3. R. E. Moore, AIRDOS--A Computer Code for Estimating Population and Individual Doses Resulting from Atmospheric Releases of Radionuclides from Nuclear Facilities, ORNL-TM-4687 (1974).

4. "Final Environmental Statement Related to the Haddam Neck (Connecticut Yankee) Nuclear Power Plant," Directorate of Licensing, U. S. Atomic Energy Commission, Docket No. 50-213, October 1973.

5. F. Pasquil1, Atmospheric Diffusion, D. van Nostrand Co., Ltd., New York, 1962.

6. David H. S1ade, ed., Meteorology and Atomic Energy, 1968, Division of Technical Information, U. S. Atomic Energy Commission, Oak Ridge, Tennessee, 1968, p. 40.

7. Title 10, Atomic Energy, Part 50, "Licensing of Production and Utilization Facilities," Code of Federal Register, Vol. 36, No. 111.

8. International Commission on Radiological Protection, Recommendations of the International Commission on Radiological Protection, ICRP Publication 9, Pergamon Press, London, 1966. 
9. D. K. Trubey and S. V. Kaye, The EXREM III Computer Code for Estimating External Radiation Doses to Populations from Environmental Releases, ORNL-TM-4322 (1973).

10. W. D. Turner, S. V. Kaye, and P. S. Rohwer, EXREM and INREM Computer Codes for Estimating Radiation Doses to Populations from Construction of a Sea-Level Canal with Nuclear Explosives, K-1752, Oak Ridge Gaseous Diffusion Plant, Oak Ridge, Tennessee, 1968.

11. 1969 Census of Agriculture, U. S. Department of Commerce, Social and Economic Statistics Administration, Bureau of the Census, June 1972. 
ORNL-TM-4781

UC -41 - Health and Safety

INTERNAL DISTRIBUTION

1. S. I. Auerbach

2. J. A. Auxier

3. C. J. Barton

4. F. T. Binford

5. B. G. Blaylock

6. R. S. Booth

7. R. L. Burgess

8. T. J. Burnett

9. F. H. Clark

10. C. C. Coutant

11. W. B. Cottrel1

12. F. L. Culler

13. R. C. Dahlman

14. B. E. Dinger

15. J. O. Duguid

16. C. E. Easterly

17. W. F. Harris, III

18. R. F. Hibbs

19. G. S. Hill

20. F. B. K. Kam

$21-45$. S. V. Kaye

46. G. D. Kerr

47. G. G. Killough, Jr.

48. R. E. Moore

49. D. J. Nelson

50. F. R. O'Donnell
51. R. V. O'Neill

52. D. C. Parzyck

53. H. Postma

54. J. W. Poston

55. D. E. Reichle

56. C. R. Richmond

57. P. S. Rohwer

58. E. G. Struxness

59-63. F. H. Sweeton

64. J. E. Till

65. J. R. Trabalka

66. D. K. Trubey

67 . V. R. R. Uppuluri

68. R. I. Van Hook

69. J. P. Witherspoon

70-79. RSIC Library

80-89. Computer Sciences Division Library

90-92. Central Research Library

93. ORNL - Y-12 Technical Library Document Reference Section

94-98. Laboratory Records Department

99. Laboratory Records, ORNL R.C.

100. ORNL Patent Office

EXTERNAL DISTRIBUTION

101. Lee Aamodt, Los Alamos Scientific Laboratory, P. O. Box 1663, Los Alamos, New Mexico 87544.

102. Advanced Research Projects Agency, Department of Defense, The Pentagon, Washington, D. C. 20301.

103. L. R. Anspaugh, University of California, Lawrence Livermore Laboratory, Livermore, California 94550.

104. David S. Ballantine, Division of Biological and Environmental Research, U.S. Energy Research and Development Administration, Washington, D. C. 20545.

105. R. F. Barker, Product Standards Branch, Directorate of Regulatory Standards, U.S. Nuclear Regulatory Commission, Washington, D. C. 20545. 
106. Nathaniel F. Barr, Division of Biomedical and Environmental Research, U.S. Energy Research and Development Administration, Washington, D. C. 20545.

107. D. S. Barth, National Environmental Research Center, EPA, P. O. Box 15027, Las Vegas, Nevada 89114.

108. Martin B. Biles, Director, Division of Operational Safety, U.S. Nuclear Regulatory Commission, Washington, D. C. 20545.

109. J. A. Blasy, Division of Applied Technology, U.S. Energy Research and Development Administration, Washington, D. C. 20545.

110. Andre Bouville, United Nations, Scientific Committee on the Effects of Atomic Radiation, New York, New York 10016.

111. J. A. Broadway, Eastern Environmental Research Facility, P. 0. Box 61 , Montgomery, Alabama 36101.

112. Carter D. Broyles, Department Manager, Test Sciences (7110), Sandia Corp., P. 0. Box 5800, Albuquerque, New Mexico 87115.

113. W. W. Burr, Jr., Division of Biology and Medicine, U.S. Energy Research and Development Administration, Washington, D. C. 20545.

114. Murray Calkins, National Environmental Research Center, Environmental Protection Agency, Cincinnati, Ohio 45268.

115. M. W. Carter, Interdisciplinary Sciences, Georgia Institute of Technology, Atlanta, Georgia 20332.

116. Eddie W. Chew, El Paso Natural Gas Co., P. O. Box 1492, El Paso, Texas 79999.

117. J. G. Christian, Office of Radiation Programs, U.S. Environmental Protection Agency, 401 M St. SW, Washington, D. C. 20460.

118. Roger J. Cloutier, Special Training Division, Oak Ridge Associated Universities, Oak Ridge, Tennessee 37830.

119. R. G. Cochrei1, Manager, Licensing Division, Westinghouse Electric Corporation, P. 0. Box 158, Madison, Pennsylvania 15663.

120. Jerry Cohen, Lawrence Livermore Laboratory, P. O. Box 808, Livermore, California 94551.

121. Jared J. Davis, Office of Nuclear Regulatory Research, U. S. Nuclear Regulatory Commission, Washington, D. C. 20545

122. Raymond D. Cooper, Division of Biomedical and Environmental Research, U.S. Energy Research and Development Administration, Washington, D. C. 20545.

123. Paul J. Cory, Office of the Secretary of Transportation, Washington, D. C. 20590.

124. George A. Cowan, Los Alamos Scientific Laboratory, P. O. Box 1663, Los Alamos, New Mexico 87544.

125. T. V. Crawford, Savannah River Laboratory, E. I. du Pont de Nemours \& Company, Aiken, South Carolina 29801.

126. R. G. Cuddihy, Inhalation Toxicology Research Institute, 5200 Gibson BIvd. SE, Albuquerque, New Mexico 87108.

127. Richard Cunningham, Division of Materials Licensing, U.S. Nuclear Regulatory Commission, Bethesda, Maryland 20014.

128. Adrian H. Dah1, U.S. Energy Research and Development Administration, Idaho Operations Off Ice, 550 2nd St., Idaho Falls, Idaho 83401.

129. L. J. Deal, Division of Biomedical and Environmental Research, U.S. Energy Research and Development Administration, Washington, D. C. 20545 . 
130. N. J. Diaz, Dept. Nuclear Engineering Sciences, University of Florida, Gainesville, Florida 32601.

131. Bennie DiBona, Director, Division of Peaceful Applications, Nevada Operations Office, U.S. Energy Research and Development Administration, P. 0. Box 1676, Las Vegas, Nevada 89101.

132. Richard L. Blanchard, Radiochemistry \& Nuclear Engineering Facility, U. S. Environmental Protection Agency, Cincinnati, Ohio 45268

133. P. B. Dunaway, Office of Effects Evaluation, Nevada Operations Office, U.S. Energy Research and Development Administration, Las Vegas, Nevada 87114.

134. G. G. Eichholz, School of Nuclear Engineering, Georgia Institute of Technology, Atlanta, Georgia 20332.

135. Rudolf J. Engleman, Division of Biomedical and Environmental Research, U.S. Energy Research and Development Administration, Washington, D. C. 20545.

136. Edward H. Fleming, University of California Lawrence Libermore Laboratory, Mail Stop L-1, Box 808 Livermore, California 94550

137. R. Franklin, Division of Biomedical and Environmental Research, U.S. Energy Research and Development Administration, Washington, D. C. 20545.

138. Carl Gamertsfelder, Directorate of Licensing, U.S. Nuclear Regulatory Commission, Washington, D. C. 20545.

139. Mahlon Gates, Manager, Nevada Operations Office, U.S. Energy Research and Development Administration, P. 0. Box 1676, Las Vegas, Nevada 99101.

140. F. A. Gifford, Jr., Air Resources Atmospheric Turbulence and Diffusion Laboratory, NOAA, Oak Ridge, Tennessee 37830.

141. S. Yaniv, Office of Nuclear Regulatory Research, Mail Stop Al-3002, U. S. Nuclear Regulatory Commission, Washington, D. C. 20555

142. Abraham S. Goldin, Kresge Center for Environmental Health, Harvard University, School of Public Health, Boston, Massachusetts 02100.

143. R. S. Goor, National Science Foundation, 2101 Constitution Ave., Washington, D. C. 20418.

144. R. L. Gotchy, Directorate of Licensing, U.S. Energy Research and Development Administration, Washington, D. C. 20545.

145. Douglas Grahn, Argonne National Laboratory, 9700 South Cass Avenue, Argonne, I11inois 60439

146. Harold J. Groh, Jr., Separations Chemistry, Savannah River Laboratory, E. I. duPont de Nemours and Company, P. O. Box "A", Aiken, South Carolina 29802.

147. S. R. Hanna, Air Resources Atmospheric Turbulence and Diffusion Laboratory, NOAA, Oak Ridge, Tennessee 37830.

148. J. E. Hardaway, Surveillance and Analysis Division, Technical Support Branch, Suite 900, 1860 Lincoln Street, Denver, Colorado 80203 .

149. W. R. Hardwick, U.S. Bureau of Mines, Eight West Paseo Redondo, Tucson, Arizona 85705.

150. D. F. Harmon, Office of Regulation, U.S. Nuclear Regulatory Commission, Bethesda, Maryland 20014. 
151. Monte Hawkins, Head, Safety and Environmental Control, Allied General Nuclear Services, P. 0. Box 847, Barnwe11, South Carolina 29812.

152. J. W. Healy, Health Physics Division, Los Alamos Scientific Laboratory, Box 1663, Los Alamos, New Mexico 87544.

153. John Heslep, Chief, Environmental Safety and Consumer Protection Program, State Department of Public Health, 2151 Berkeley Way, Berkeley, California 97404.

154. Gary H. Higgins, K. Division, Lawrence Livermore Laboratory, P. 0. Box 808 (L-41), Livermore, California 94551.

155. George Hinman, Gulf Central Atomic, Box 608, San Diego, California 92112.

156. I. A. Hobbs, Director, Technical and Production Division, Savannah River Operations Office, P. 0. Box "A", Aiken, South Carolina 29802.

157. John B. Hursh, Department of Radiation Biology and Biophysics, University of Rochester, Rochester, New York 14620.

158. Stephen Jinks, Institute of Environmental Medicine, New York University Medical Center, Long Meadow Road, Tuxedo, New York 10987.

159. B. Kahn, Interdisciplinary Sciences, Georgia Institute of Technology, Atlanta, Georgia 20332.

160. Jacob Kastner, Radiological Assessment Branch, Directorate of Licensing, U.S. Nuclear Regulatory Comission, Washington, D. C. 20545.

161. J. Kline, Argonne National Laboratory, Radiological Physics Division Ecological Studies, Argonne, Illinois 60439.

162. J. Koranda, Biomedical Division, Lawrence Radiation Laboratory, P. 0. Box 808 (L-13), Livermore, California 94551.

163. Paul Kruger, Professor of Nuclear Chemistry, Department of Civil Engineering, Stanford University, Stanford, Cal ifornia.

164. William Martin, Battelle Memorial Institute, 505 King Avenue, Columbus, Ohio 43201.

165. P. J. Me11 inger, EXXON Nuclear Company, 2955 George Washington Way, Richland, Washington 99352

166. M. L. Merritt, Underground Physics Division (5232), Sandia Corporation, Albuquerque, New Mexico 87115.

167. Peter McGrath, ORG 1721, Sandia Laboratories, Albuquerque, New Mexico 87113.

168. W. A. Mills, U.S. Environmental Protection Agency, Criteria and Standards Division, 401 M St., SW, Washington, D. C. 20460.

169. M. T. Mills, GCA Technical Division, Burlington Road, Bedford, Massachusetts 01730.

170. A. A. Moghissi, Office of Interdisciplinary Studies, Georgia Institute of Technology, Atlanta, Georgia 20332.

171. K. Z. Morgan, School of Nuclear Engineering, Georgia Institute of Technology, Atlanta, Georgia 20332.

172. Henry W. Morton, Nuclear Fuel Services, Inc., 6000 Executive Blvd., Suite 600, Rockville, Maryland 20852.

173. D. R. Nelson, Office of Radiation Programs, U.S. Environmental Protection Agency, 401 M Street, S. W., Washington, D. C. 20460. 
174. Randolph R. Newton, Division of Biological and Environmental Research, U.S. Energy Research and Development Administration, Washington, D. C. 20545.

175. T. R. Noonan, UT-AEC Agricultural Research Laboratory, 1299 Bethe1 Valley Road, Oak Ridge, Tennessee 37830.

176. Donald A. Nussbaumer, Directorate of Licensing, U.S. Nuclear Regulatory Comission, Washington, D. C. 20545.

177. H. T. Odum, Department of Environmental Engineering, University of Florida, Gainesville, Florida 32601.

178. W. Ogle, Los Alamos Scientific Laboratory, P. O. Box 1663, Los Alamos, New Mexico 87544.

179. M. J. Ohanian, Head, Department of Nuclear Engineering Sciences, University of Florida, Gainesville, Florida 32601.

180. J. S. 01son, Division of Biomedical and Environmental Research, U.S. Energy Research and Development Administration, Washington, D. C. 20545.

181. W. S. Osburn, Division of Biomedical and Environmental Research, U.S. Energy Research and Development Administration, Washington, D. C. 20545.

182. Charles Osterberg, Division of Biomedical and Environmental Research, U.S. Energy Research and Development Administration, Washington, D. C. 20545

183. Aaron Padgett, Carolina Power and Light, P. O. Box 1551, Raleigh, North Carolina 27602.

184. C. C. Palmiter, Office of Radiation Programs, Environmental Protection Agency, 401 M Street, SW, Washington, D. C. 20460.

185. F. L. Parker, Department of Civil Engineering, Vanderbilt University, Nashville, Tennessee 37203.

186. Michae1 A. Parsont, Radiological Assessment Branch, Directorate of Licensing, U.S. Nuclear Regulatory Commission, Washington, D. C. 20545.

187. H. R. Payne, U.S. Environmental Protection Agency Region IV, 1421 Peachtree St., Atlanta, Georgia 30309.

188. W. H. Pennington, Division of Biomedical and Environmental Research, U.S. Energy Research and Development Administration, Washington, D. C. 20545.

189. Paul Phelps, University of California, Lawrence Radiation Laboratory, Livermore, Cal ifornia 94550.

190. J.F. Phili ip, Director, Special Projects Division, San Francisco Operations office, U.S. Atomic Energy Commission, 2111 Bancroft Way, Berkeley, California 94704.

191. K. Purushothamon, University of Missouri at Rolla, Rolla, Missouri 65401.

192. W. H. Ray, Office of Regulation, U.S. Nuclear Regulatory Commission, Bethesda, Maryland 20014.

193. L. Roberts, School of Nuclear Engineering, Georgia Institute of Technology, Atlanta, Georgia 20332.

194. Alvin M. Weinberg, Institute for Energy Analysis, Oak Ridge Associated Universities, Oak Ridge, Tennessee 37830

195. J. N. Kogers, Division 8321, Sandia Laboratories, P. O. Box 969, Livermore, California 94550. 
196. Milton E. Rose, Mathematical and Computer Sciences Program, Molecular Sciences and Energy Research, Division of Physical Research, U.S. Energy Research and Development Administration, Washington, D. C. 20545.

197. H. C. Rothschild, Radiation Protection Bureau, Brookfield Road, Ottawa KIAIC1, Ontario, Canada.

198. Paul Russe11, Research Director, Denver Mining Research Center, U.S. Bureau of Mines, Denver Federal Bullding, Denver, Colorado 80225.

199. Lewis M. Schalit, Systems, Science and Software, P. 0. Box 1620, La Jolla, California 92037.

200. Keith J. Schiager, University of Pittsburg, Radiation Center, Pittsburg, Pennsyivania 15213

201. G. A Selme1, Diviston of Biology and Medicine, Battelle Pacific Northwest Laboratories, Richland, Washington 99352.

202. Clifford S. Selvage, Manager, Advance Systems Research Department 1, Sandia Corp., P. 0. Box 969, Livermore, California 94550.

203. Seymour Shwiller, Staff Member, Joint Comittee on Atomic Energy, Congress of the United States, Washington, D. C. 20510.

204. C. F. Smith, Jr., Lawrence Livermore Laboratory, P. 0. Box 808, Livermore, Cal ifornia 94551.

205. David S. Smith, Office of Radiation Programs, U.S. Environmental Protection Agency, 401 M Street, SW, Washington, D. C. 20460.

206. Harold Sohns, U.S. Bureau of Mines, Laramie Petroleum Research Center, Laramie, Wyoming 82071.

207. J. K. Soldat, Pacific Northwest Laboratories, Battelle Memorial Institute, Richland, Washington.

208. Jeff Swinebroad, Division of Biomedical and Environmental Research, U.S. Energy Research and Development Administration, Washington, D. C. 20545 .

209. Lauriston Taylor, National Academy of Sciences, Advisory Committee on Emergency Planning, 2101 Constitution Avenue, Washington, D. C. 20418.

210. Howard Tewes, Lawrence Livermore Laboratory, P. 0. Box 808, Livermore, California 94551.

211. Paul C. Tompkins, 407 Clayton Road, Chapel Hill, North Carolina 27514

Las Vegas, Nevada 89101.

212. J. H. Tormey, Corps of Engineers, Assistant Director of Civil Works for Nuclear Construction Planning, Department of the Army, Washington, D. C. 20315.

213. A. N. Tse, Product Standards Branch, Directorate of Regulatory Standards, U.S. Nuclear Regulatory Commission, Washington, D. C. 20545.

214. William S. Twenhofe], U.S. Geological Survey, Federal Center, Denver, Colorado 80225.

215. B. H. Van Domelen, Governor's Science Adviser, Sandia Laboratory, 1820, Albuquerque, New Mexico 87115.

216. R. Watters, Division of Biomedical and Environmental Research, U.S. Energy Research and Development Administration, Washington, D. C. 20545. 
217. James E. Watson, Jr., Radiological Hygfene Branch, Tennessee Valley Authority, River Oaks Building, Muscle Shoals, Alabama 35630 .

218. Glenn C. Werth, Associate Director for Plowshare, Lawrence Livermore Laboratory, P. 0. Box 808 (L-13), Livermore, Cal ifornia 94551 .

219. F. W. Whicker, Department of Radiology and Radiation Biology, Colorado State University, Ft. Collins, Colorado 80521.

220. L. Schwartz, Lawrence Livermore Laboratory, P. 0. Box 808. Livermore, California 94551.

221. B. G. Wixson, University of Missouri at Rolla, Rolla, Missouri 65401 .

222. R. W. Wood, Division of Biology and Medicine, U.S. Energy Research and Development Administration, Washington, D. C. 20545.

223. Claude Yarbro, Research and Technical Support Division, ERDA-ORO Oak Ridge, Tennessee 37830.

224. Richard Graves, Assistant Superintendent, Connecticut Yankee Nuclear Power Station, RR \#1, Box 127E, East Hampton, Connecticut 06424.

225-469. Given distribution as shown in TID-4500 under category Health and Safety (25 copies - NTIS) 